\title{
Management of Postharvest Decay in Carrot (Daucus carota L. var. sativus) through Eco-friendly Approaches
}

\author{
S. Vanitha*, P. Murali Sankar, A.S. Krishnamoorthy, G. Karthikeyan and K. Prabakar
}

Department of Plant Pathology, CPPS, TNAU, Coimbatore, India

*Corresponding author

\section{A B S T R A C T}

K e y w o r d s
Carrot, Eco-
friendly, Soft rot,
Postharvest loss,
Lemongrass oil

\section{Introduction}

Carrot (Daucus carota L. var. sativus) is one of the most important root vegetable crop in the world. Mostly, it was cultivated for their nutritional status of $\alpha$ and $\beta$ carotene, vitamins (A, B6 and $\mathrm{K}$ ), minerals ( $\mathrm{Ca}$ and potassium) with edible fibre (Heinonen, 1990). Naturally, it was grown in the temperate regions with high humidity agro-ecosystems. Under global wide, about $60 \%$ of carrot production has shared by Asia alone. In India, carrot was cultivated around 108 thousand ha. with production of $1626 \mathrm{M}$. tonnes (NHB, 2019). Under Tamil Nadu, carrot cultivation has been done at 3000 ha. with production of
107.3 M. tonnes through productivity of 26.2 tonnes / ha. Normally, all root vegetables were shelf-life oriented and highly perishable nature due to occurrence of fungal and bacterial diseases were accompanied with atmospheric changes and poor storage conditions from field to postharvest. So, it causes severe product and economic loss from harvest to before consumption for farmers, sellers and consumers (Seljasen et al., 2013). Especially, during cusine preparations it gave annoying experience to the women in the kitchenary.

In major diseases of carrot viz., Alternaria blight, cavity spots and damping off ( $P$. violae 
and $P$. sulcatum), powdery mildew, white mold (S. sclerotiorum) bacterial blight (X. campestris pv. carotae) and soft rots or postharvest decay (E. carotovora subsp. carotovora and E. chrysanthemi) causing severe yield loss 50-100\% from field to storage under favourable conditions (Bhat et $a l ., 2010)$. Among them, soft rot causing $E$. carotovora subsp. carotovora (Ecc) as a ubiquitous seed and soilborne nature, rod shaped, gram negative bacterium and causing complete loss due to their easily survival nature, rapid colonization, prevalence and regeneration of bio-competence ability (Czajkowski et al., 2011). Mostly it survived under moist soil conditions $>50 \%$ and temperature around $27-30^{\circ} \mathrm{C}$ with drizzling rainy conditions on temperate regions. This bacterium as a polyphagous nature on wide host specificity in the major food crops. Under pathogenic nature, it was synthesized the pectinolytic and cellulolytic enzymes for rapid infection and to a produce typical watery lesions and rots (Clark et al., 1998). Spreading of this disease through wounds and infected seed inoculum during harvest to storage conditions due to improper handling of transit accompanied with imbalance of atmospheric conditions (Barkai-Golan and Phillips, 1991). Using fungicides and chemicals towards against soft rots were provided the on- time relief and makes a slow toxigenic for who intakes their diet regularly (Utama et al., 2010).

Using the safest alternative strategies viz., botanicals [Ecc P-138 / jute and cheerota] (Rahman et al., 2012), [P. carotovora subsp. carotovora / turmeric 30\%] - (Adamu et al., 2017); plant volatile compounds such as acetaldehyde, benzaldehyde, cinnamaldehyde, benzyl alcohol, have also been found to have antifungal activity against the fruit and vegetable pathogens viz., A. alternata, $P$. digitatum, $R$. stolonifer, Colletotrichum musae and Erwinia carotovora during in vitro trials (Almenar et al., 2008; Abd Alla et al., 2008). Using organic acids such as acetic acid, boric acid and calcium hypochlorite (bleaching powder) were completely retarded the growth and infection of soft rot pathogen $P$. carotovoroa subsp. carotovora (P 138) under storage conditions (Rahman et al., 2017). The organic salts like aluminium chloride, sodium thiosulfate, sodium benzoate were inhibited the growth Pectobacterium sp. in poato at modified atmospheric storage conditions (Betchem et al., 2019). An oil of spearmint (Mentha piperita L.) at $0.5 \%$ controlled the disease severity $(>33 \%)$ of soft rot in cabbage $c v$. Natsume when during spraying (Guerra et al., 2014).

Keep these views, the work was carried out for management of postharvest decaying pathogen in carrot through eco-friendly approaches viz., botanicals, plant volatiles, organic acids, organic salts and essential oils under controlled atmospheric conditions.

\section{Materials and Methods}

\section{Selection of strain}

The virulent strain was selected on the basis of pathogenic nature and it was isolated from infected portion of carrot surface sterilized with $0.1 \%$ sodium hypochlorite solution (for 30 seconds) and washed with sterile distilled water, then ground the samples within $0.85 \%$ saline solution using sterile mortar and pestle under aseptic conditions. The bacterial suspension was left undisturbed for few minutes and it was vortexed at high speed for 60seconds for uniform homogenization. Aseptically, the bacterial suspension was tenfold diluted in sterile saline solution $(0.85 \%$, w/v). A loop ful of diluted suspension was streaked to the plates containing YEPA (yeast extract peptone agar) medium and incubated at $28^{\circ} \mathrm{C}$ for 24 hours (Rahman et al., 2017). 
Antibacterial activity of eco-based properties against to Ecc

\section{Botanicals}

\section{Preparation of plant extracts}

A total of nine plants viz., white mustard (Sinapis alba), myrobalan (Terminalia chebula), Malabar tamarind (Garcinia gummugutta), giant milk weed (Calotropis gigantean), adathoda (Adathoda vesical), ashwagantha (Withania somnifera), Indian coleus (Coleus forskohlii), clove (Syzygium aromaticum) and cinnamon (Cinnamomum zeylanicum) were tested against with $E$. carotovora subsp. carotovora. Dried leaves were collected and it was grinded with distilled water 1:1 (w/v) by using sterilized pestle and mortar. Then filtered through double layered muslin cloth at least two times. The filtered extract was kept in conical flasks and closed with aluminium foil and preserved at $4^{\circ} \mathrm{C}$ for further uses.

\section{In vitro assay}

A fresh sterilized YPDA medium was amended with plant extracts at (1:10) ratio and it was poured in the Petri dishes and wait few minutes for the solidification. After, a testing virulent strain of Ecc was streaked on the Petri dishes and kept under $28^{\circ} \mathrm{C}$ for 48 hours. An observation was recorded on the basis for the presence of growth nature by positive (+) (present) or negative (-) (absent) in Petri dishes (Rahman et al., 2012).

\section{Plant volatiles}

Three different synthetic plant volatile compounds such as benzaldehyde, benzyl alcohol and thymol were used as different concentrations viz., 10,15 and $20 \%$. The sterilized volatile compounds were amended with volume of $(10 / 15 / 20 \mathrm{ml}$ per $100 \mathrm{ml}$
YPDA medium). These volatiles inoculated medium was poured in the Petri dishes and allowed for solidification at few minutes. After a virulent strain of $E c c$ was streaked on the Petri dishes and kept under $28^{\circ} \mathrm{C}$ for 48 hours. A growth observation was recorded on the basis of positive (present $^{+}$) or negative (absent ${ }^{-}$) (Huang et al., 2011).

\section{Organic acids}

Five different organic acids viz., boric acid, lactic acid, acetic acid, propionic acid and citric acid were used in the three different concentration viz., $0.5,0.75$ and $1.0 \%$. Before adding the organic acids, the concentrations were prepared and adding in sterilized YPDA (Yeast Peptone Dextrose Agar) medium and it was poured in sterilized Petri plates for allowing solidification for few minutes. After the $48 \mathrm{hrs}$ old $E c c$ strain was taken and make a gentle streak and control was maintained without any organic acids. Inoculated plates were kept under $28^{\circ} \mathrm{C}$ for 48 hours. A growth observation was recorded on the basis of positive $\left(\right.$ present $\left.^{+}\right)$or negative (absent ${ }^{-}$) (Rahman et al., 2017).

\section{Organic salts}

The nine different organic salts such as, EDTA, copper sulphate, sodium molybdate, sodium bicarbonate, sodium carbonate, sodium acetate, potassium chloride, calcium chloride and ammonium acetate were used as different concentration viz., 0.5, 1.0, 2.0 and $4.0 \%$. The salts were prepared as stock in 100 $\mathrm{ml}(\mathrm{w} / \mathrm{v})$ and prepared stock was taken as required volume $(\mathrm{v} / \mathrm{v})$ was added in the sterilized tryptic soy agar (TSA) medium. After the organic salts amended medium 15 $\mathrm{ml} /$ each was poured in the Petri dishes. A pure culture of Ecc has streaked on the plates containing medium and control was kept without salts. These plates were kept under $28^{\circ} \mathrm{C}$ for 48 hours. The growth observation 
was recorded by the descriptions given by Yaganza et al. (2014).

\section{Essential oils}

The eight different aromatic-medicinal oils viz., Lemongrass (Cymbopogon citratus), Cinnamon (Cinnamomum zeylanicum), Thyme (Thymus vulgaris), Wintergreen (Gaultheria procumbens), Citronella (Pelargonium citrosum) Citriodora (Backhousia citriodora), Eucalyptus (Eucalyptus camaldulensis) and Clove (Syzgium aromaticum) were used as four different concentrations like, $0.1,0.5,1.0$ and $2.0 \%$. Testing oils were dispersed in distilled water to obtain required concentrations $(0.1$, $0.5,1.0$ and $2.0 \%)(\mathrm{v} / \mathrm{v})$ mixed with Tween 20 (1:1) and well agitated. Each oil was amended with sterilized YPDA medium separately and poured in Petri dishes and allowed for solidification. A well grown $48 \mathrm{hrs}$ old Ecc strain was streaked on the Petri dishes containing medium and kept in $28^{\circ} \mathrm{C}$ for 48 hours. Control plate was kept without oil. An observation was recorded on the basis of culture growth (Guerra et al., 2014).

\section{Curative efficacy of eco-based consortia against to postharvest decay in carrot}

Based on the results of the in vitro test, botanical (Cinnamon bark extract - 10\%), plant volatiles (Benzaldehyde and Thymol $10 \%$ ), organic acid (Acetic acid - 0.5\%), organic salt (Calcium chloride $2.0 \%$ and EC formulated essential oils like, lemongrass, cinnamon and thyme were used as $0.1 \%$ concentrations. A well prepared eco-based consortia (EC formulated solution) was used and the freshly harvested carrots $(200 \mathrm{~g})$ were dipped in 15 minutes and kept in sterilized plastic trays under $28^{\circ} \mathrm{C}$ for two weeks (Controlled atmosphere) and maintained with completely randomized design. Healthy control was maintained without treatments.
The following treatment details were given in the table 1 .

\section{Observations}

The treated carrots decay incidence and per cent of weight loss $(\%)$ were recorded from 14 days after application from the formula described by Abd-El-Khair and Karima (2007) and Utama et al. (2014).

Per cent of decay $(\%)=$

No. of infected Carrots $\times 100$

Total No. of Carrots

Weight loss $(\%)=$

$\underline{\text { Initial Weight }- \text { After treated Weight }} \times 100$ Initial Wight

After application of eco-based consortia, the treated carrots were observed from first day to 10 days on the phenomic and sensory nature via., appearance, colour, flavour, texture taste and overall edible acceptance were checked on the basis of scale (9 to 1 - Highly acceptable to Not acceptable) (Hajhamed et al., 2007).

\section{Results and Discussion}

\section{Antibacterial activity of eco-based properties against to $E c c$}

The antibacterial activity of eco-based properties viz., botanicals, plant volatiles, organic acids, organic salts and essential oils were checked against to Ecc under in vitro conditions.

\section{Botanicals}

Totally nine botanicals were for antibacterial efficacy against Ecc under in vitro among them, cinnamon (Cinnamomum zeylanicum) 
was completely inhibited the growth of $E$. carotovora subsp. carotovora (Table 1; Fig 1). The results revealed that cinnamon had antibacterial compounds of (E) cinnamaldehyde and proanthocyanidins are against to food borne and multi-drug resistant pathogenic bacteria viz., L. monocytogenes, $S$. aureus, E. coli, S. anatum (Liang et al., 2019), $B$. cereus, and $P$. aeruginosa under laboratory conditions (Bin Chan et al., 2007; El Atki et al., 2020).

\section{Plant volatiles}

In three plant volatile compounds, benzaldehyde and thymol were significantly inhibited the bacterial growth under least conc. of $10 \%$ (Table 1; Fig 2). These results revealed that benzaldehyde completely inhibited the sporogenesis of $B$. cinerea and M. fructicola at 25 and $125 \mu \mathrm{l} / \mathrm{L}$. Under mycelial inhibition, three volatile compounds viz., benzaldehyde, methyl salicylate and ethyl benzoate were inhibited the mycelial growth at conc. of $370 \mu \mathrm{l} / \mathrm{L}$ (Wilson and Wisniewski, 1989). Normally benzaldehyde used as protectant for peaches from Rhizopus rot under storage godowns (Utama et al., 2002).

\section{Organic acids and salts}

Out of five organic acids and nine salts, acetic acid, citric acid at $0.5 \%$ and copper sulphate and calcium chloride at $2.0 \%$ were completely inhibited the growth of E. carotovora subsp. carotovora (Table 2; Fig 2). The results revealed with chemicals like, acetic acid, boric acid and calcium hypochlorite were inhibited the potato soft rot pathogen $P$. carotovora subsp. carotovora at $0.05 \%$ conc. under in vitro (Rahman et al., 2017). Under laboratory conditions, low molecular concentration of salts viz., aluminium salts, sodium benzoate, sodium metabisulfite, potassium sorbate and trisodium phosphate were completely inhibited the growth of $F$. sambucinum causing dry rot in potato (Mecteau et al., 2002).

\section{Essential oils}

Out of these eight oils, lemongrass oil, cinnamon oil and thyme oil were most effectively inhibited the growth of $E$. carotovora subsp. carotovora at minimal concentration of $0.1 \%$ (Table 3; Fig 3). These results confirmed with Jeong et al. (2009) reported that lemongrass oil, inhibited the growth of $P$. carotovora subsp. carotovora at $0.5 \%$ concentration. Clove oil gives a better growth inhibition against $X$. campestris $p v$. vesicatoria causing bacterial spot in tomato (Lucas et al., 2012).

\section{Curative efficacy of eco-based consortia against to postharvest decay of carrot}

During the bioassay, all the eco-based consortia were significantly reduced the incidence of decay in carrot contributed in weight loss also. Among them, treatment like (T2) carrots were dipped in EC formulated three oils (Cinnamon oil + Lemongrass oil + Thyme oil) based consortia at $0.1 \%$ was recorded as very least per cent $(2.0 \%)$ of decay and weight loss $(3.0 \%)$ with maximum per cent reduction at $98.0 \%$ compared than others (Table 4; Table 5; Fig 4). It also recorded better improvements in the preservation and edible qualities viz., appearance, colour, flavour, texture, taste with overall acceptability. These results are revealed that Utama et al. (2014) reported that oil-water emulsion of sesame $(0.5 \%)$ and lemongrass oil $(0.5 \%)$ was reduced the fruit rot and weight loss in tomato under room conditions. This failure of decay incidence due to the presence of antimicrobial compounds like citral and geraniol. Both are inhibited the mycelial growth and sporogenesis of A. flavus and A. fumigatus on tomato (Karkala and Genjalawa, 2009). 
Table.1 Antibacterial activity of different botanicals and plant volatiles against with E. carotovora subsp. carotovora. under in vitro

\begin{tabular}{|c|c|c|c|c|c|c|}
\hline \multirow[t]{2}{*}{ S. No. } & \multirow[t]{2}{*}{ Name of the botanicals } & \multirow[t]{2}{*}{$\begin{array}{c}\text { Antibacterial activity } \\
\text { (growth) }\end{array}$} & \multirow[t]{2}{*}{ Name of the Plant Volatiles } & \multicolumn{3}{|c|}{$\begin{array}{c}\text { Concentrations \& Antibacterial } \\
\text { activity (growth) }\end{array}$} \\
\hline & & & & $10 \%$ & $15 \%$ & $20 \%$ \\
\hline 1. & $\begin{array}{c}\text { Sinapis alba } \\
\text { (White mustard) }\end{array}$ & + & Benzaldehyde & - & - & - \\
\hline 2. & $\begin{array}{l}\text { Terminalia chebula } \\
\text { (Myrobalan) }\end{array}$ & + & Benzyl alcohol & + & + & + \\
\hline 3. & $\begin{array}{l}\text { Garcinia gummugutta } \\
\text { (Malabar tamarind) }\end{array}$ & + & Thymol & - & - & - \\
\hline 4. & $\begin{array}{l}\text { Calotropis gigantean } \\
\text { (Giant milk weed) }\end{array}$ & + & Control & + & + & + \\
\hline 5. & $\begin{array}{l}\text { Adathoda vesical } \\
\text { (Adathoda) }\end{array}$ & + & & & & \\
\hline 6. & $\begin{array}{l}\text { Withania somnifera } \\
\text { (Ashwagantha) }\end{array}$ & + & & & & \\
\hline 7. & $\begin{array}{l}\text { Coleus forskohlii (Indian } \\
\text { Coleus) }\end{array}$ & + & & & & \\
\hline 8. & $\begin{array}{l}\text { Syzygium aromaticum } \\
\text { (Clove) }\end{array}$ & + & & & & \\
\hline 9. & $\begin{array}{c}\text { Cinnamomum zeylanicum } \\
\text { (Cinnamon) }\end{array}$ & - & & & & \\
\hline 10. & Control & + & & & & \\
\hline
\end{tabular}

(+: Growth / -: No growth) 
Table.2 Antibacterial activity of different organic acids and organic salts against with E. carotovora subsp. carotovora under in vitro

\begin{tabular}{|c|c|c|c|c|c|c|c|c|c|}
\hline \multirow{2}{*}{$\begin{array}{c}\text { S. } \\
\text { No. }\end{array}$} & \multirow[t]{2}{*}{ Organic acids } & \multicolumn{3}{|c|}{ Concentrations (\%) } & \multirow[t]{2}{*}{ Organic salts } & \multicolumn{4}{|c|}{ Concentrations (\%) } \\
\hline & & 0.5 & 0.75 & 1.0 & & 0.5 & 1.0 & 2.0 & 4.0 \\
\hline 1. & Boric acid & + & + & + & EDTA & + & + & + & + \\
\hline 2. & Lactic acid & + & + & + & Copper sulphate & - & - & - & - \\
\hline 3. & Acetic acid & - & - & - & Sodium molybdate & + & + & + & + \\
\hline 4. & Propionic acid & + & + & + & Sodium bicarbonate & + & + & + & + \\
\hline 5. & Citric acid & - & - & - & Sodium carbonate & + & + & + & + \\
\hline 6. & Control & + & + & + & Sodium acetate & + & + & + & + \\
\hline 7. & & & & & Potassium chloride & + & + & + & + \\
\hline 8. & & & & & Calcium chloride & + & + & - & - \\
\hline 9. & & & & & Ammonium acetate & + & + & + & + \\
\hline 10 & & & & & Control & + & + & + & + \\
\hline
\end{tabular}

(+: Growth / -: No growth) 
Table.3 Antibacterial activity of different essential oils against with E. carotovora subsp. carotovora under in vitro

\begin{tabular}{|c|c|c|c|c|c|}
\hline \multirow[t]{2}{*}{ S. No. } & \multirow[t]{2}{*}{$\begin{array}{c}\text { Name of the essential oils } \\
\text { used }\end{array}$} & \multicolumn{4}{|c|}{$\begin{array}{c}\text { Concentrations }(\%) \& \text { bacterial growth } \\
\qquad(+/-)\end{array}$} \\
\hline & & 0.1 & 0.5 & 1.0 & 2.0 \\
\hline 1. & Lemongrass oil & - & - & - & - \\
\hline 2. & Cinnamon oil & - & - & - & - \\
\hline 3. & Thyme oil & - & - & - & - \\
\hline 4. & Wintergreen oil & + & + & + & + \\
\hline 5. & Citronella oil & + & + & + & + \\
\hline 6. & Citriodora oil & + & + & + & + \\
\hline 7. & Eucalyptus oil & + & + & + & + \\
\hline 8. & Clove oil & + & + & + & + \\
\hline 8. & Control & + & + & + & + \\
\hline
\end{tabular}

(+: Growth / -: No growth).

Table.4 Management of postharvest decay in carrot by eco-based consortia under in vitro

\begin{tabular}{|c|c|c|c|c|}
\hline T. No. & Treatment details & $\begin{array}{c}\text { Decay } \\
(\%)\end{array}$ & $\begin{array}{l}\text { Per cent } \\
\text { decay } \\
\text { over } \\
\text { control }\end{array}$ & $\begin{array}{l}\text { Weight } \\
\text { loss } \\
(\%)\end{array}$ \\
\hline T1. & $\begin{array}{l}\text { Dipping freshly harvested carrot with boiled bark } \\
\text { extract of Cinnamon }(10 \%)\end{array}$ & $9.0^{b}$ & 91.0 & 11.0 \\
\hline $\mathbf{T} 2$. & $\begin{array}{l}\text { Dipping freshly harvested carrot with EC } \\
\text { formulated essential oils (Cinnamon oil, Lemon } \\
\text { grass oil and Thyme oil) @ } 0.1 \% \text { conc. }\end{array}$ & $2.0^{\mathrm{a}}$ & 98.0 & 3.0 \\
\hline T3. & $\begin{array}{l}\text { Dipping freshly harvested with carrot organic } \\
\text { Acetic acid }(0.5 \%)\end{array}$ & $34.0^{c}$ & 66.0 & 23.0 \\
\hline T4. & $\begin{array}{l}\text { Dipping freshly harvested carrot with organic salts } \\
\text { calcium chloride }(2.0 \%)\end{array}$ & $49.5^{e}$ & 50.5 & 50.0 \\
\hline T5. & $\begin{array}{l}\text { Fumigated with Benzaldehyde }(10 \%) \text { and stored } \\
\text { the freshly harvested carrot }\end{array}$ & $54.5^{\mathrm{f}}$ & 45.5 & 58.5 \\
\hline T6. & $\begin{array}{l}\text { Fumigated with Thymol (10\%) and stored the } \\
\text { freshly harvested carrot }\end{array}$ & $59.5^{\mathrm{g}}$ & 40.5 & 61.0 \\
\hline T7. & Healthy Control & $38.0^{d}$ & 62.0 & 43.0 \\
\hline T8. & Inoculated control & $100.0^{h}$ & - & 69.0 \\
\hline & S Ed. & \multicolumn{3}{|c|}{6.01} \\
\hline & $\mathrm{CD}(\mathrm{P}<0.05)$ & \multicolumn{3}{|c|}{1.94} \\
\hline
\end{tabular}

Values are mean of three replications.

Means followed by a common letter are not significantly at $5 \%$ level by DMRT. 
Table.5 Phenomic and organo-sensory tests for best eco-based consortia treated carrot against postharvest decay

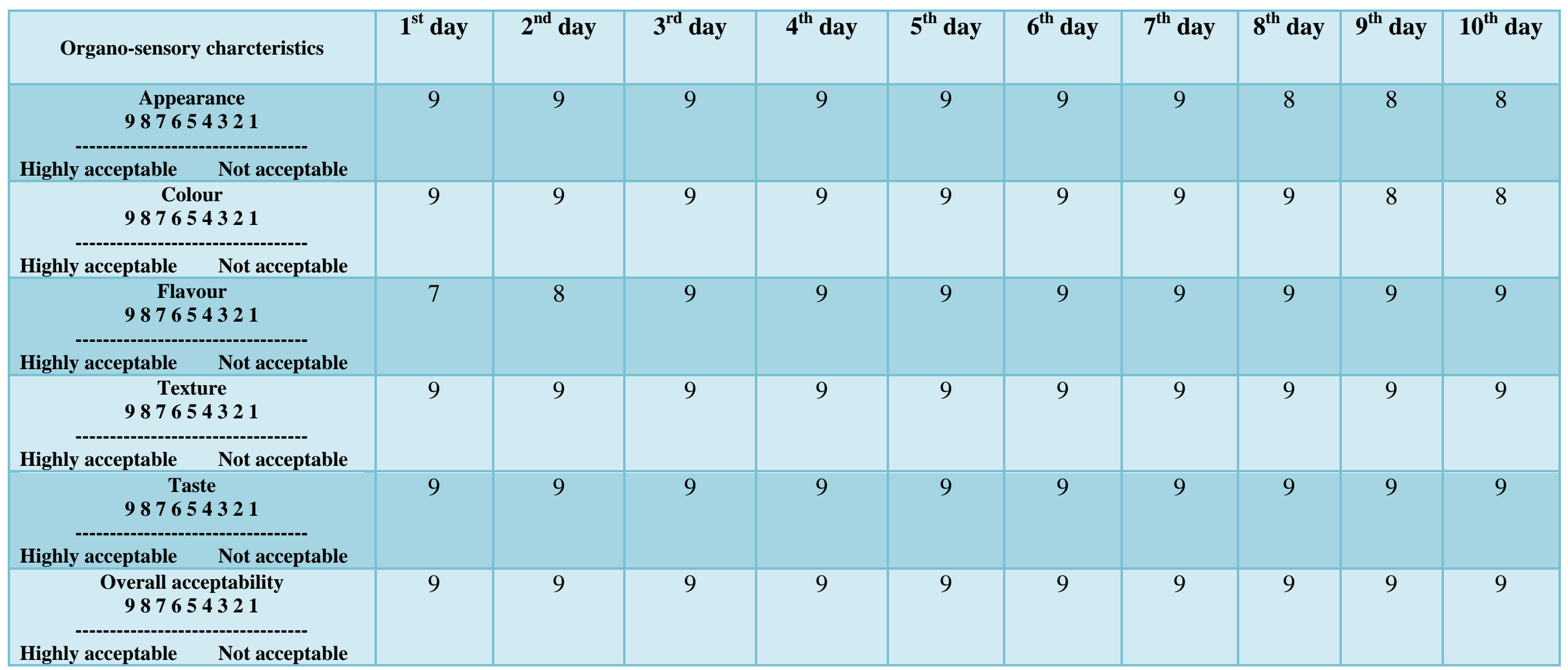


Figure.1 Antibacterial activity of different botanicals against with E. carotovora subsp. carotovora under in vitro
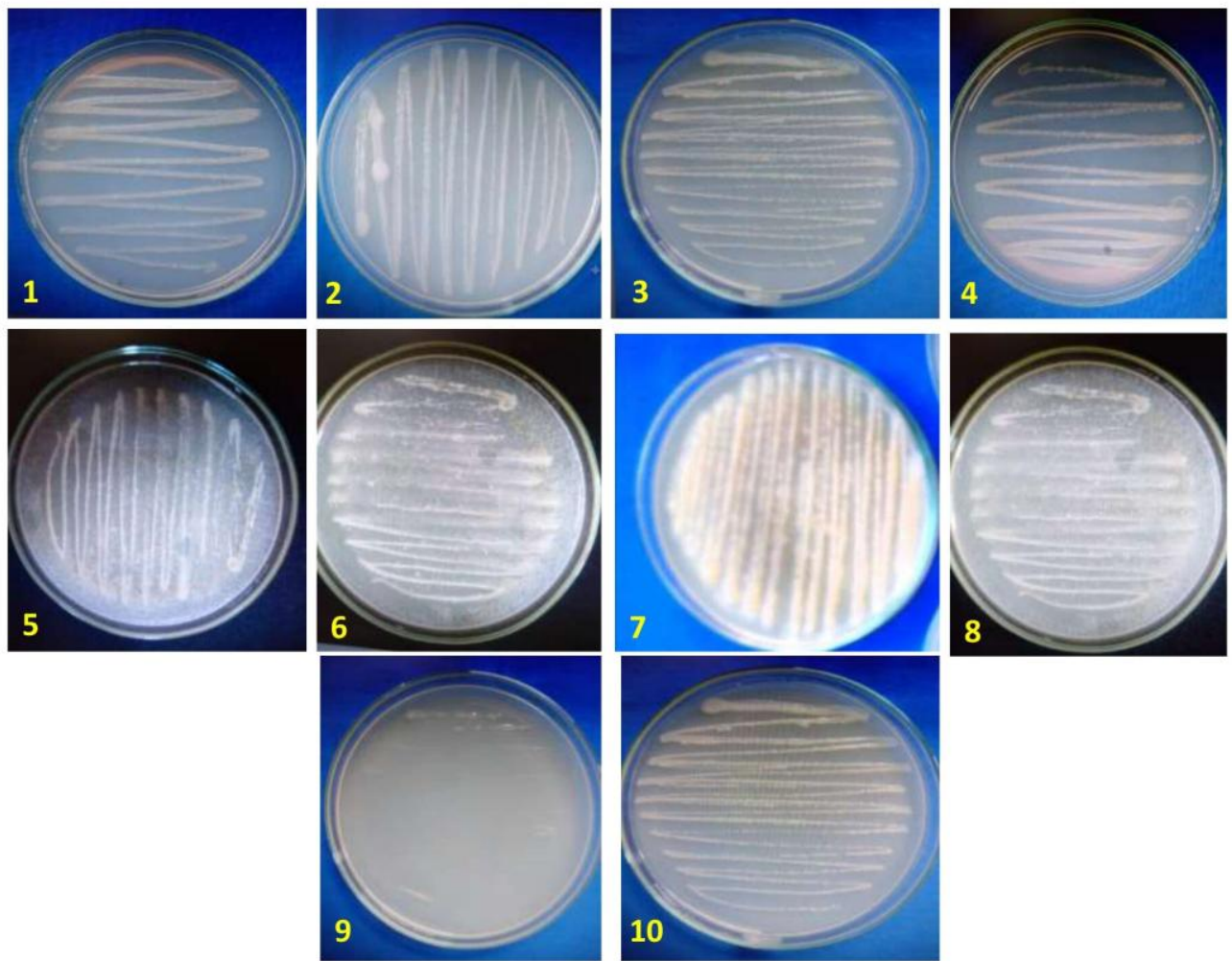

\section{List of botanicals}

1. White mustard

6. Ashwagantha

2. Myrobalan

7. Indian Coleus

3. Malabar tamarind

8. Clove

4. Giant milk weed

9. Cinnamon

5. Adathoda

10. Control 
Figure.2 Antibacterial activity of different plant volatiles, organic acids and salts against with E. carotovora subsp. carotovora under in vitro

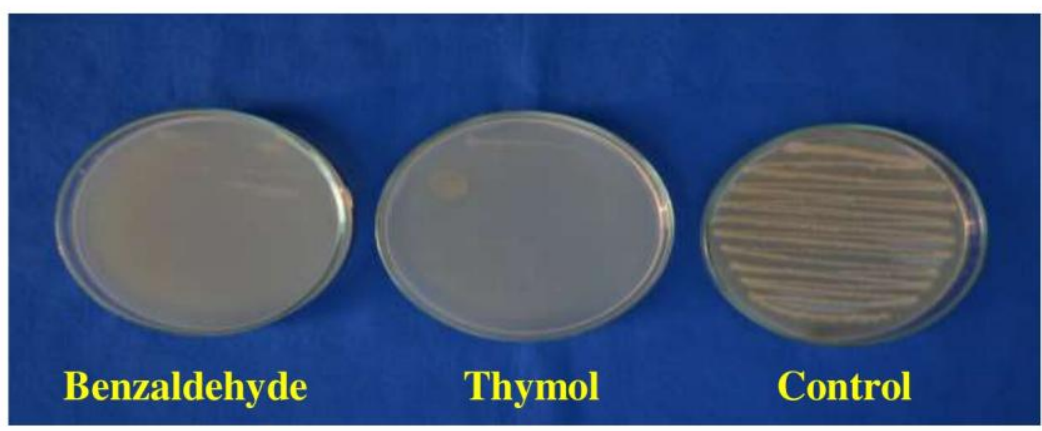

Plant Volatiles

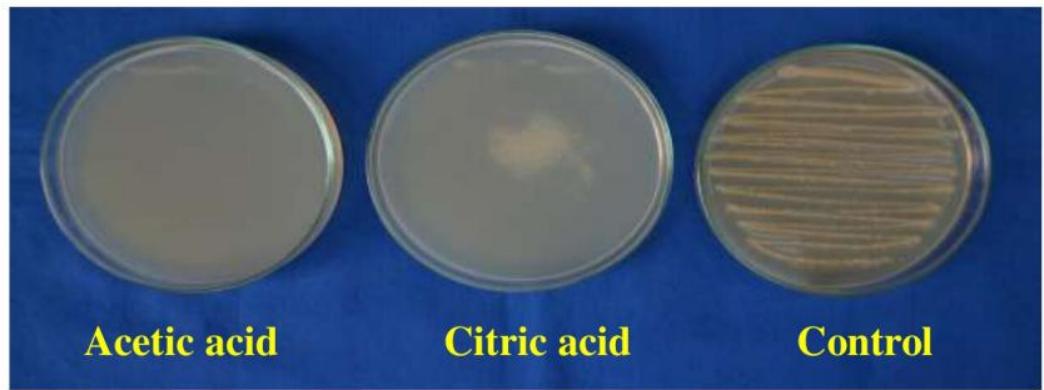

Organic Acids

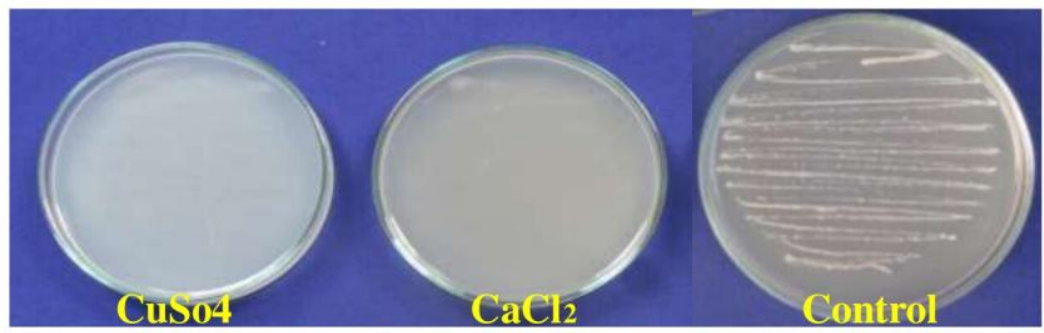

Organic Salts

Plant volatiles@10\% Conc.

Organic acids @ 0.5\%

Organic salts @ $0.5 \%\left(\mathrm{CuSo}_{4}\right)$ and $2.0 \%\left(\mathrm{CaCl}_{2}\right)$ 
Figure.3 Antibacterial activity of different essential oils against with E. carotovora subsp. carotovora under in vitro

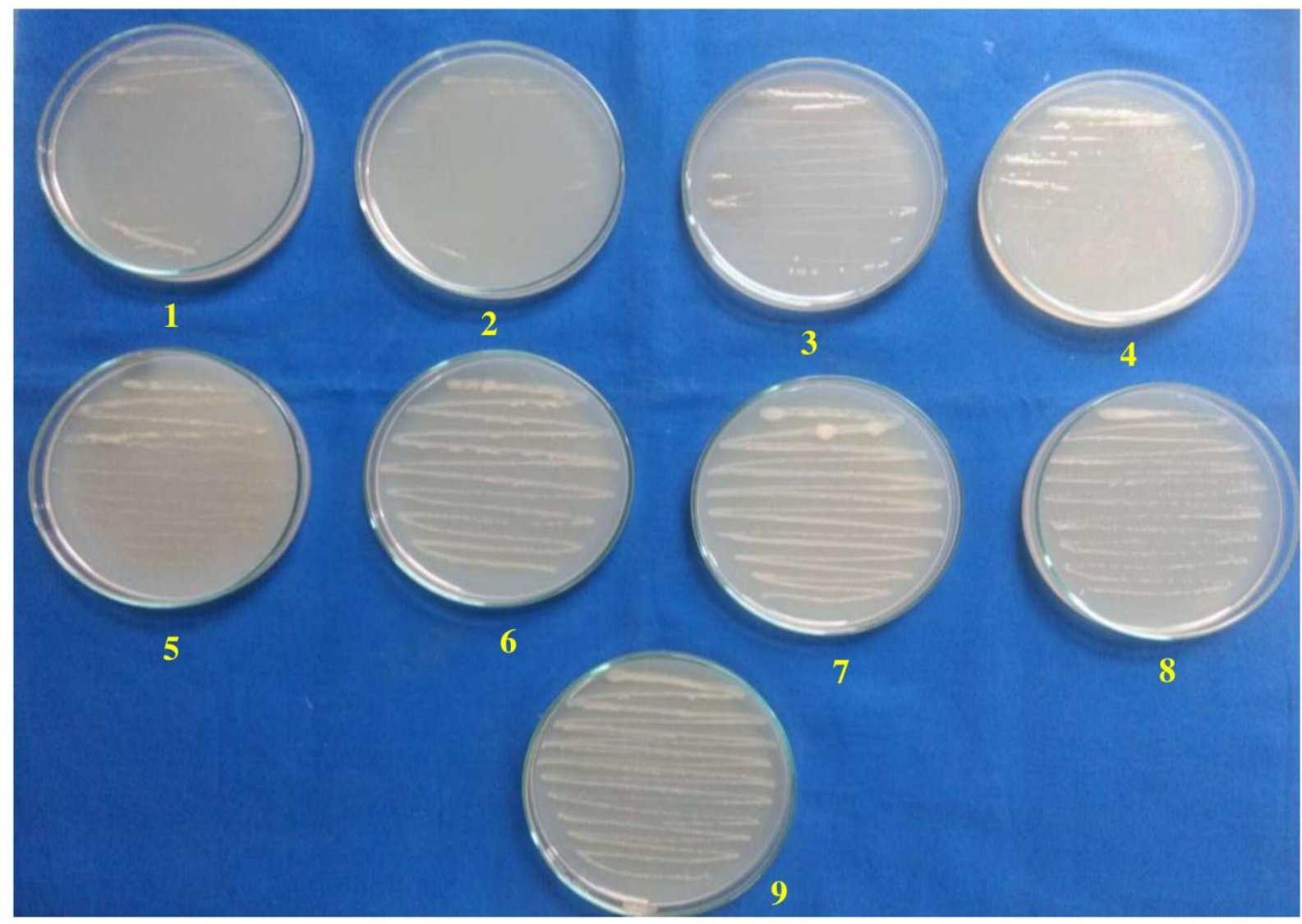

List of essential oils (0.1\% conc.)

1. Lemongrass oil 6. Citriodora oil

2. Cinnamon oil 7. Eucalyptus oil

3. Thyme oil Clove

4. Wintergreen oil 9. Control

5. Citronella oil 
Figure.4 Management of postharvest decay in carrot through eco-friendly approaches under in vitro

a. Inoculated control

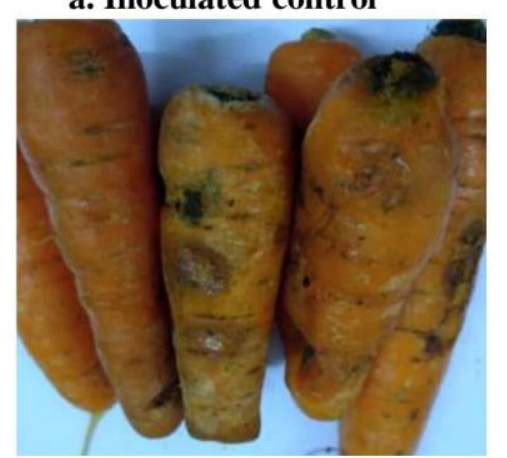

b. Healthy control
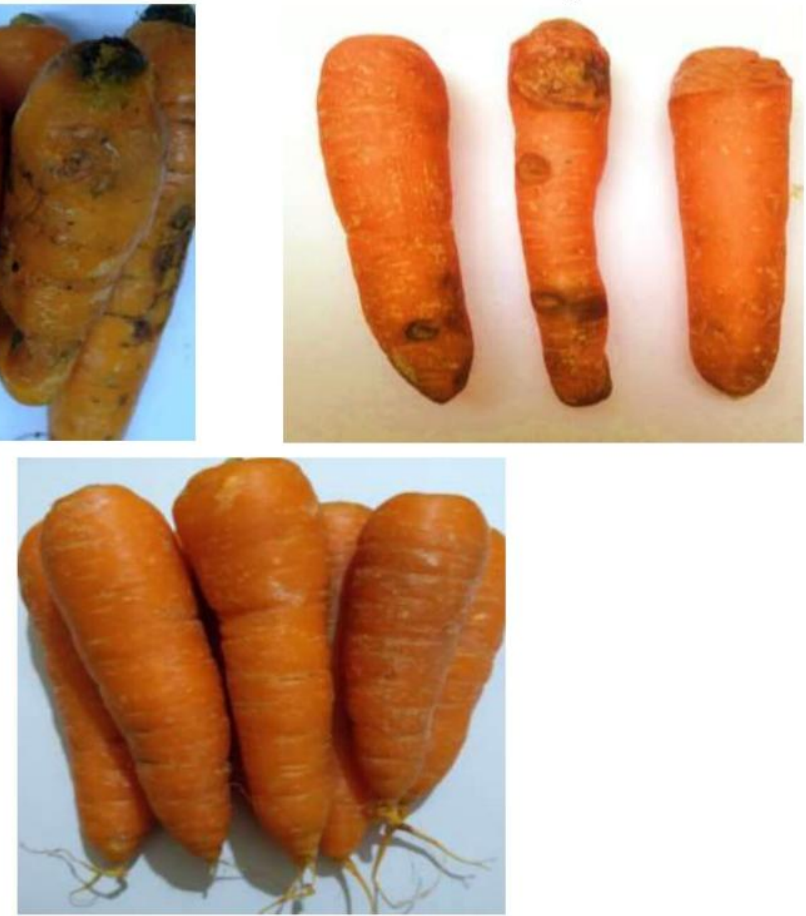

c. EC formulated cinnamon + lemongrass + thyme oil consortia
During cinnamon oil with combined application at low concentration was given a better result against to postharvest pathogens and causing decay in fruits and vegetables with avoiding perishable nature due to single antimicrobial compound of transcinnamaldehyde (Unlu et al., 2010).

It is concluded that naturally, edible fruits and vegetables are discarded before on our eating plate due to highly influence of pathogens and causing diseases. It was occurred with association of agro-climatic factors from preharvest to consumption with improper harvesting, handling issues, poor storage. Carrot (Daucus carota L. var. sativus) is one of the most infected root vegetable and occurring by decay causing pathogens after harvest. About these results, the carrot was treated with EC formulation of cinnamon, lemongrass and thyme oil at $0.1 \%$ were preserved the vegetable nature and avoid the decay incidence and pathogen's invasion due to the formation of biofilm and exploration of antimicrobial compounds under room conditions.

\section{Fund Source}

Carrot - Sub Project, Non Plan Scheme, TNAU, Coimbatore, India.

\section{Acknowledgements}

DST-FIST Lab, Department of Plant Pathology, CPPS, TNAU, Coimbatore, India.

New Trichoderma Lab, Department of Plant 
Pathology, CPPS, TNAU, Coimbatore, India.

\section{References}

Abd Alla, M. A., El Sayed Ziedan, H. and ElMohamedy, R. S. 2008. Control of Rhizopus rot disease of apricot fruits (Prunus armeniaca L.) by some plant volatile aldehydes. Res. J. Agric. Biol. Sci., 4: 424-433.

Abd-El-Khair, H. and Karima, H. E. H. 2007. Application of some bactericides and bioagents for controlling the soft rot disease in potato. Res J. of Agrl. Biol Sci., 3 (5): 463-473.

Adamu, S. H., Lal, A. A. and Simon, S. 2017. In vitro efficacy of certain botanicals against soft rot of tomato (Solanum lycopersicum L.). African J. Agrl Res., 12 (23): 2049- 2055.

Almenar, E., Samsudin, H., Auras, R., Harte, B. and Rubino, M. 2008. Postharvest shelf life extension of blueberries using a biodegradable package. Food Chem., 110 (1): 120- 127.

Barkai-Golan, R. and Phillips, D. J. 1991. Postharvest heat treatment of fresh fruits and vegetables for decay control. Plant Dis., 75: 1085-1089.

Betchem, G., Nkuma Jhonson, N. A. and Wang, Y. 2019. The application of chitosan in the control of post-harvest diseases: a review. J. Plant Dis. Prot., s41348-019-00248-2: 1- 14.

Bhat, K. A., Masood, S. D., Bhat, N. A., Ashraf Bhat, M., Razvi, S. M., Mir, M. R., Akhtar, S., Wani, N. and Habib, M. 2010. Current status of postharvest soft rot in vegetables: a review. Asian $J$. Plant Sci., 9 (4): 200-208.

Bin Shan, B., Yi-Zhong Cai, Y., Brooks, J. D. and Corke, H. 2007. Antibacterial properties and major bioactive components of cinnamon stick (Cinnamomum burmannii): activity against foodborne pathogenic bacteria. $J$.
Agric. Food Chem., 55 (14): 5484- 5490.

Clark, C. A., Hoy, M. W., Bond, J. P., Chen, C., Goh, Y. K., Liang, X., Liu, X. and Lotrakul, P. 1998. First report of Erwinia carotovora subsp. carotovora causing Bacterial root rot of sweet potato (Ipomoea batatas) in Louisiana. Plant Dis., 82 (1): 129.

Czajkowski, R., Pe'rombelon, M. C. M., van Veen, J. M. and van der Wolf, J. M. 2011. Control of blackleg and tuber soft rot of potato caused by Pectobacterium and Dikeya species: a review. Plant Pathol., 60: 999-1013.

El Atki, Y., Aouam, I., El Kamari, F., Taroq, A., Nayme, K., Timinouni, M., Lyoussi, B. and Abdellaoui, A. 2020. Antibacterial activity of cinnamon essential oils and their synergistic potential with antibiotics. J. Adv. Pharm. Technol. Res., 10: 63-67.

Guerra, M. L., Guerra, Y. L., de Souza, E. B. and Ramos Mariano, R. L. 2014. Essential plant oils in reducing the intensity of soft rot in Chinese cabbage. Rev. Cienc. Agron., 45 (4): 760-766.

Hajhamed, A. A., Sayed, W. M. A. E., Yazied, A. A. E. and Ghaffar, N. Y. A. E. 2007. Suppression of bacterial soft rot disease of potato. Egyptian $J$. Phytopathol., 35 (2): 69-80.

Heinonen, M. I. 1990. Carotenoids and provitamin-A activity of carrot (Daucus carota L.) cultivars. J Agric Food Chem., 38:609-612.

Huang, R., Li, G. Q., Zhang, J., Yang, L., Che, H. J., Jiang, D. H. and Huang, H. C. 2011. Control of postharvest Botrytis fruit rot of strawberry by volatile organic compounds of Candida intermedia. Phytopathol., 101 (7): 859-869.

Jeong, M. R., Beom Park, P., Kim, D. H., Jang, Y. S., Jeong, H. S. and Choi, S. H. 2009. Essential oil prepared from Cymbopogon citrates exerted an antimicrobial activity against plant 
pathogenic and medical microorganisms. Mycobiol., 37 (1): 48-52.

Karkala, S. and Genjalawa, D. 2009. Antimicrobial activity of essential oils of four lemongrass varieties. Med. Aromatic Plant Sci. Biotechnol., 3: 1007109.

Liang, Y., Li, Y., Sun, A. and Liu, X. 2019. Chemical compound identification and antibacterial activity evaluation of cinnamon extracts obtained by subcritical n-butane and ethanol extraction. Food Sci. Nutri., 7 (6): 2186-2193.

Lucas, G. C., Alves, E., Pereira, R. B., Zacaroni, A. B., Jose Perina, F. and Magela de Souza, R. 2012. Indian clove essential oil in the control of tomato bacterial spot. J. Plant Pathol., 94 (1): 45-51.

Mecteau, M. R., Arul, J. and Tweddell, R. J. T. 2002. Effect of organic and inorganic salts on the growth and development of Fusarium sambucinum, a causal agent of potato dry rot. Mycol. Res., 106 (6): 688696.

NHB, 2019. In report: Area and Production of Horticulture Crops: All India. National Horticultural Board, India. p. 1-3.

Rahman, M. M., Khan, A. A., Ali, M. E., Mian, H., Akanda, A. M. and Abdhamid, S. B. 2012. Botanicals to control soft rot bacteria of potato. The Scientific World $J .$, p. 1-6.

Rahman, M. M., Khan, A. A., Mian, I. H., Akanda, A. M. and Alam, M. Z. 2017. Effect of some chemicals on incidence of potato soft rot disease in Bangladesh. Bangladesh J. Sci. Ind. Res., 52 (2): 135140.

Seljasen, R., Kristensen, H. L., Lauridsen, C., Wyss, G. S., Kretzschmar, U., es Birlouez- Aragone, I. and Khal, J. 2013. Quality of carrots as affected by pre- and postharvest factors and processing. $J$ Sci.
Food Agric., 93: 2611-2626.

Unlu, M., Ergene, E., Unlu, G. V., Zeytinoglu, H. S. and Vural, N. 2010. Composition, antimicrobial activity and in vitro cytotoxicity of essential oil from Cinnamomum zeylanicum, Blume (Lauraceae). Food Chem.Toxicol., 48: 3274-80.

Utama, I. M. S., Wills, R. B. H., Antara, I. N. S., Mandrini, I. A. B. and Kencana, P. K. D. 2010. The efficacy of acetaldehyde vapour against the growth of soft rot bacteria (Erwinia carotovora) inoculated on Capsicum fruits. In: Proceedings of the National Seminar on Horticulture, Udayana University, Indonesia, pp. 436444.

Utama, I. M. S., Wills, R. B. H., BenYouoshua, S. and Kuek, C. 2002. In vitro efficacy of plant volatiles for inhibiting the growth of fruit and vegetable decay microorganisms. J. of Agric. Food Chem., 50: 6371-6377.

Utama, I. M. S., Yulianti, N. L., Prastya, O. A. and Luther, G. 2014. Sesame and lemongrass oils as coating materials to reduce the deterioration of tomato fruits during storage. In: Proceedings of the National Seminar of Indonesian Horticultural Society, MalangIndonesia. pp. 1-9.

Wilson, C. L. and Wisniewski, M. E. 1989. Biological control of postharvest diseases of fruits and vegetables: an emerging technology. Annu. Rev. Phytopathol., 27: 425-441.

Yaganza, E. S., Tweddell, R. J. and Arul J. 2014. Postharvest application of organic and inorganic salts to control potato (Solanum tuberosum L.) storage soft rot: plant tissue- salt physiochemical interactions. J. Agric. Food Chem., 62 (38): 9223-9231. 
How to cite this article:

Vanitha, S., P. Murali Sankar, A.S. Krishnamoorthy, G. Karthikeyan and Prabakar, K. 2020. Management of Postharvest Decay in Carrot (Daucus carota L. var. sativus) through Ecofriendly Approaches. Int.J.Curr.Microbiol.App.Sci. 9(06): 3924-3939.

doi: https://doi.org/10.20546/ijcmas.2020.906.461 